\title{
Phytoplankton biomass and nutrient dynamics in a tidally induced upwelling: the role of the $\mathrm{NO}_{3}: \mathrm{SiO}_{4}$ ratio
}

\author{
Maurice E. Levasseur, Jean-Claude Therriault
}

Maurice-Lamontagne Institute, Department of Fisheries and Oceans, PO Box 1000, 850 route de la Mer, Mont-Joli, Quebec G5H 3Z4, Canada

\begin{abstract}
Data from 2 cruises in July 1979 and 1980 in the head region of the Laurentian Channel, in the St. Lawrence estuary, were used to study variations of nutrient and phytoplankton biomass following upwelling relaxation. During both cruises, the newly upwelled water mass was characterized by high salinity $(>29 \%)$, low temperature $\left(<4{ }^{\circ} \mathrm{C}\right)$, low phytoplankton biomass $\left(<1 \mu \mathrm{g} \mathrm{l} \mathrm{l}^{-1}\right)$ and high nutrient levels $\left(\mathrm{NO}_{3}=13 \mu \mathrm{M}, \mathrm{PO}_{4}=1.4 \mu \mathrm{M}, \mathrm{SiO}_{4}=18 \mu \mathrm{M}, \mathrm{NH}_{4}=0.6 \mu \mathrm{M}\right)$. As the water mass warmed up, phytoplankton biomass increased exponentially up to $\sim 17 \mu \mathrm{g} \mathrm{l}^{-1}$ and a concurrent decrease in the concentration of all nutrients was observed. The decrease of $\mathrm{NO}_{3}: \mathrm{PO}_{4}$ and $\mathrm{NO}_{3}: \mathrm{SiO}_{4}$ ratios during this period indicates a gradual nitrate impoverishment of the mixed layer. At the warmest stations, in July 1980, nitrate and ammonium reached undetectable concentrations while silicic acid concentrations fell below $2 \mu \mathrm{M}$. High values of phytoplankton POC: PON ratios measured in July 1980 also suggest that. algae were nitrogen limited during this cruise. Data from this study and other world-wide upwelling areas support the hypothesis that the initial concentration of nitrate and silicic acid in the newly upwelled waters is the factor which mainly determines which nutrient will become exhausted (limiting) first. The nearly simultaneous exhaustion of nitrate and silicic acid in the St. Lawrence estuary is attributed to the 3-layer circulation pattern of its water masses. Silicic acid is trapped in the bottom layer (deeper than $100 \mathrm{~m}$ ) which is hardly mixed with surface waters. In the intermediate layer (between 20 and $100 \mathrm{~m}$ ), the origin of the upwelled waters, these 2 nutrients are generally found in equal proportion.
\end{abstract}

\section{INTRODUCTION}

High primary productivity in upwelling areas results mainly from the rapid growth of diatom species (net plankton) following the surface injection of nutrientrich subsurface waters. Although these areas are often characterized by high secondary productivity levels, relatively few studies have reported severe phytoplankton growth limitation by zooplankton grazing (see Boyd \& Smith 1983 for an example). Usually, phytoplankton biomass accumulation was found to be limited by available nitrate (Harrison et al. 1981, Huntsman et al. 1981, Jones et al. 1981) or occasionally silicic acid (Dugdale 1972, Brink et al. 1981). Kamykowski (1974) was the first to suggest that the initial level of these 2 nutrients in a recently upwelled water mass played a fundamental role in the phytoplankton dynamics by determining which nutrient became exhausted first. Further studies have effectively revealed that the silicic acid and nitrate depletions generally found in surface waters of the Peru and California upwelling regions, respectively, corresponded to a latitudinal trend in their relative abundance (Zentara \& Kamykowski 1977). Moreover, Dugdale (1983) suggested that the temporal shift from silicic acid to nitrate limitation of diatom growth often observed in the Peru upwelling is the result of variations in the nitrate to silicic acid ratio in the newly upwelled waters. Although this hypothesis still requires further testing, the studies above suggest that phytoplankton dynamics following upwelling (or mixing) events may strongly depend on the relative initial concentrations of these 2 nutrients in the newly upwelled waters and, consequently, on the local hydrodynamic factors governing their accumulation at depth. The aim of this paper is to examine this hypothesis in the context of 2 strong upwelling events observed in the tidal upwelling system of the St. Lawrence estuary. 


\section{MATERIALS AND METHODS}

During 1979-80, 16 cruises were made to study phytoplankton dynamics in the lower St. Lawrence estuary (Therriault \& Levasseur 1985). In this paper we use the results of a grid of 13 stations from 2 cruises, July 1979 and July 1980, when particularly strong upwelling events were observed in the head region of the Laurentian channel (Fig. 1). These 2 cruises were comparable

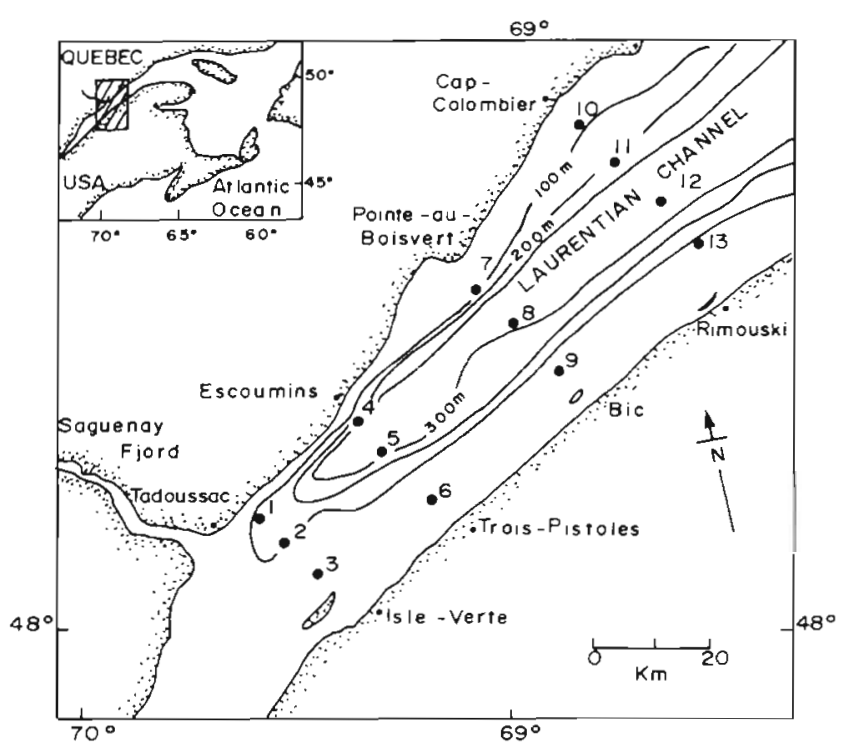

Fig. 1. Location of sampling stations in the lower St. Lawrence estuary

in terms of their seasonal dynamics since they both took place a few days after the early July spring tide.

It took $3 \mathrm{~d}$ to sample the 13 stations on both occasions. Collection and laboratory analyses of the samples are described in detail elsewhere (Therriault \& Levasseur 1985). Briefly, sampling at each station consisted of measuring water transparency (Secchi disk) and vertical profiles of temperature and salinity, and carrying out a cast of Niskin bottles at depths corresponding to $100,60,30,16$ and $1 \%$ of subsurface incident radiation and, below the photic zone, at fixed depths of $25,50,100,150,200$ and $275 \mathrm{~m}$.

Water subsamples were drawn off each Niskin bottle (between 250 and $1000 \mathrm{ml}$ ) and passed through a nylon net $(160 \mu \mathrm{m}$ mesh size) before being filtered onto $47 \mathrm{~mm}$ Whatman GF/C glass fiber filters for chlorophyll a determination and onto precombusted $25 \mathrm{~mm}$ Whatman GF/C glass fiber filters for particulate organic carbon (POC) and nitrogen (PON) determinations. The filtrate from the POC and PON filtrations was dispensed into three $50 \mathrm{ml}$ polyethylene bottles (prewashed in $0.15 \mathrm{~N} \mathrm{HCl}$ ) and stored frozen for future (within $2 \mathrm{mo}$ ) determination of ammonium, nitrate, nitrite, phosphate and silicic acid concentrations. Other subsamples were fixed with Lugol-acid and neutralized formaldehyde for phytoplankton identification and counting using the inverted microscope method (Lund et al. 1958).

In the laboratory, chlorophyll a ( $\mathrm{Chl}$ a) was measured by the fluorometric method of Yentsch \& Menzel (1963) as modified by Holm-Hansen et al. (1965). Carbon and nitrogen contents of the particulate matter collected on the filters were determined using a Perkin-Elmer model $240 \mathrm{~B}$ Elemental Analyzer. Nutrient concentrations were determined using a Technicon autoanalyzer following the methods described in Strickland \& Parsons (1972).

\section{RESULTS}

The upwelling area in the upstream region of the lower St. Lawrence estuary was evident for both sampling cruises from the relatively lower temperatures ( 2 to $6{ }^{\circ} \mathrm{C}$ ) and higher salinities $(>29 \%$ ) which were found in the surface waters along the north shore of the estuary (shaded areas in Fig.2). Very similar spatial
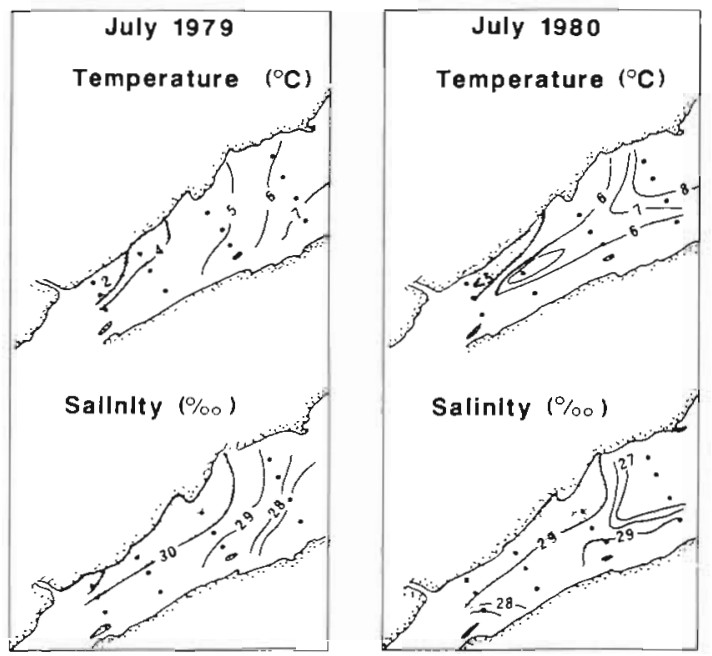

Fig. 2. Surface distribution of temperature and salinity in July 1979 and 1980 . Shaded areas delimit the upwelling zone

distribution patterns are shown for both years, even though lower temperatures and higher salinities were generally observed in 1979 than in 1980. The upwelling area comprised Stns 1, 2, 4, 5, 7 and 8 (Fig. 1) and only data from these stations were used for further analyses in this study.

\section{Temperature-salinity (T-S) characteristics}

The T-S diagrams (Fig. 3) indicate a local warming of the surface waters at the upwelling stations for both 


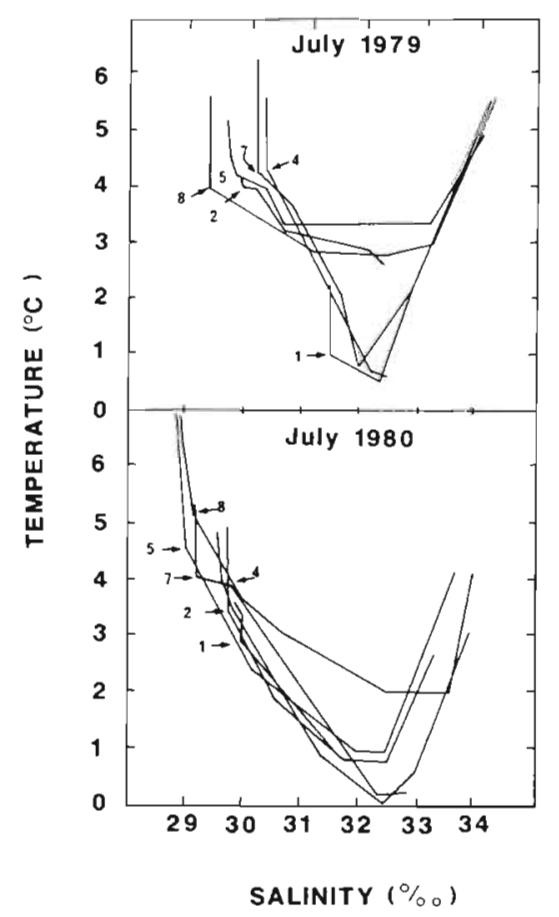

Fig. 3. T-S diagrams for each upwelling station $(1,2,4,5,7$ and 8) for July 1979 and 1980

cruises which was attributed mostly to solar heating. This was evident from the vertical rise in temperature with no change in salinity on the left-hand side of each $\mathrm{T}-\mathrm{S}$ curve. The difference in temperature between the surface and the depth of the halocline around $5 \mathrm{~m}$ for both cruises was indicative of the degree of stabilization reached upon relaxation of upwelling. The mean temperature difference between the surface and the depth of the halocline was slightly higher in July 1980 $\left(1.7 \mathrm{C}^{\circ}\right)$ than in July $1979\left(1.3 \mathrm{C}^{\circ}\right)$. This is consistent with the temporal location of each cruise as a function of the spring tide ( 2 and $4 \mathrm{~d}$ after spring tide for the 1979 and 1980 cruises, respectively), considering the fact that similar solar heating preceded each sampling cruise.

The T-S diagrams also indicate significant betweenstation variability in the temperature and salinity characteristics of the surface mixed layer during each cruise (Fig. 3). Most of this variability can be explained by 3 factors: non-synoptic sampling ( $3 \mathrm{~d}$ to sample the 13 stations), horizontal mixing, and geographical differences. Spatially, lower temperatures and higher salinities were generally observed in the upstream region (Stns 1 and 2) than in the downstream region (Stns 7 and 8 ). This is consistent with the spatial and temporal differences observed in the internal tide amplitude in the survey area (Therriault \& Lacroix 1976, Ingram 1983). Since the upwelling intensity (or tidal mixing) in the St. Lawrence is directly related to the internal tide amplitude, it was not expected that upwelling relaxation would be simultaneous all over the survey area. Gradual horizontal mixing might have also occurred between the upwelled water mass and the surrounding lower salinity waters as the upwelled water mass moved around and away from the upwelling zone. However, the fact that the mixed layer salinity characteristics changed very little and always remained $>29 \%$ during our sampling cruises suggests that these horizontal turbulent mixing changes were slow and that the upwelled waters kept their salinity characteristics for a relatively long time (certainly greater than the $3 \mathrm{~d}$ sampling time). Temperature characteristics, on the other hand, changed significantly following upwelling relaxation. Assuming that the initial physical characteristics of the upwelled waters were similar all over the upwelling area within any sampling cruise, the mean temperature differences of the mixed layer between the upwelling stations can be attributed mostly to nonsynoptic sampling and geographical variations. Therefore, surface warming (difference in mean mixed layer temperature among the stations) probably gives a good indication of the 'aging' of the upwelled water mass upon upwelling relaxation.

\section{Temperature-phytoplankton biomass relations}

Mean ( $\mathrm{n}=4$ or 5 different depths) chlorophyll $a$, POC and PON concentrations in the surface mixed layer $(\sim 5 \mathrm{~m}$ deep) were plotted for each station as function of the difference in temperature between the surface and the depth of the halocline (Fig. 4 A, B, C). Similar relations with temperature were observed for both cruises. Mean mixed layer chlorophyll $a, P O C$ and PON concentration showed a significant increase as temperature increased in the mixed layer. The mean values of the 3 biomass indices in the upwelling area were, however, generally higher in July $1980(6.6,812$ and $112 \mu \mathrm{g} \mathrm{l}^{-1}$, respectively), than in July $1979(4.9,328$ and $49 \mu \mathrm{g} \mathrm{l}^{-1}$ ).

\section{Temperature-nutrient relations}

Concurrent with the biomass increase, the mean concentration of nitrate, phosphate, silicic acid and ammonium in the mixed layer showed a drastic decrease as temperature increased for both cruises (Fig. 5). However, mean levels of nutrients were higher in the mixed layer in July $1979(8.9,1.33,13.1$ and $0.65 \mu \mathrm{M}$ for nitrate, phosphate, silicic acid and ammonium, respectively) than in July 1980 (3.3, 0.47, 6.5 and $0.53 \mu \mathrm{M})$, contrary to the biomass indices. In July 1980 , undetectable concentrations of nitrate and ammonium, 
and very low values of silicic acid and phosphate were measured in the mixed layer of the warmest stations (downstream). Ammonium concentrations were higher $(>0.6 \mu \mathrm{M})$ in the newly upwelled waters and decreased gradually to undetectable levels as the water mass warmed up. The $\mathrm{NO}_{3}: \mathrm{SiO}_{4}$ and $\mathrm{NO}_{3}: \mathrm{PO}_{4}$ ratios also showed a drastic decrease with temperature increase for both sampling cruises (Fig. 6), indicating a severe nitrate impoverishment during the bloom development. These results suggest that nutrient depletion and in particular nitrate may have restricted phytoplankton growth in the survey area. This should be reflected in the phytoplankton population and in particular in the POC : PON ratio which is known to be a useful index of nitrogen limitation (Barlow 1982a).

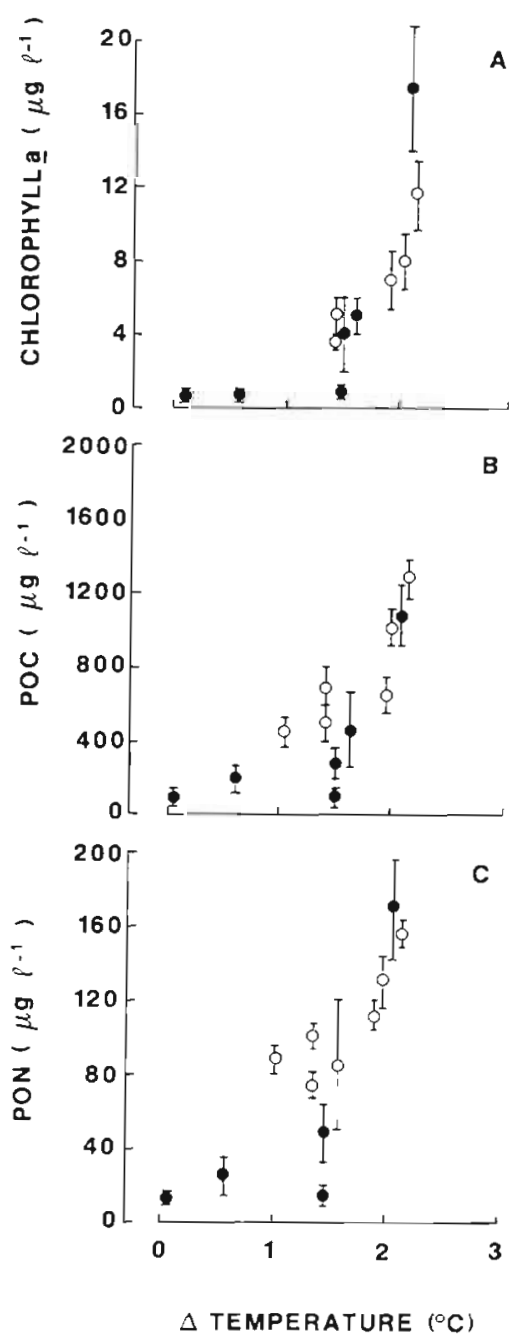

Fig. 4. Plots of temperature difference between the surface and the halocline $(\Delta t)$ against mean $\pm \mathrm{SE}$ of $(\mathrm{A})$ chlorophyll $\mathrm{a}$, (B) POC, and (C) PON concentrations measured in the mixed layer in July 1979 (0) and 1980 (o)

\section{Variations in $\mathrm{POC}: \mathrm{PON}$ ratio}

To be a useful physiological index for phytoplankton, we need to know if we are dealing with particulate carbon and nitrogen which is only related to phytoplankton. The relations between $\mathrm{Chl} a$ and POC and PON are shown in Fig. 7 for both cruises. The significant correlations calculated between those variables $\left(\mathrm{r}^{2}>0.72\right)$ indicates that the increases in both POC and PON during the warm-up of the upwelled waters were mostly due to phytoplankton biomass. Since both variables are subject to errors, the regression coefficients were estimated using a Model II regression analysis (Barttlet's 3-group method: Sokal \& Rohlf 1981). These regression coefficients are shown in Fig. 7. During the 2 cruises, the $\mathrm{Y}$-intercepts of the $\mathrm{Chl}$ a/POC regressions were very similar (111 and $139 \mu \mathrm{g} \mathrm{l}^{-1}$ ), indicating an equal amount of non-phytoplanktonic carbon. The slopes (S) of the $\mathrm{Chl}$ a/POC regressions were, however, clearly different depending on the cruises, indicating less $\mathrm{Chl}$ a per carbon unit in $1980(\mathrm{~S}=97)$ than in 1979 $(\mathrm{S}=53)$. On the contrary, the $\mathrm{Chl}$ a/PON regressions exhibited similar slopes (9.1 and 9.5) but different Yintercepts (13 and 50) for the 2 cruises (Fig. 5 B). These results indicate a larger amount of non-phytoplanktonic nitrogen in 1980 than in 1979.
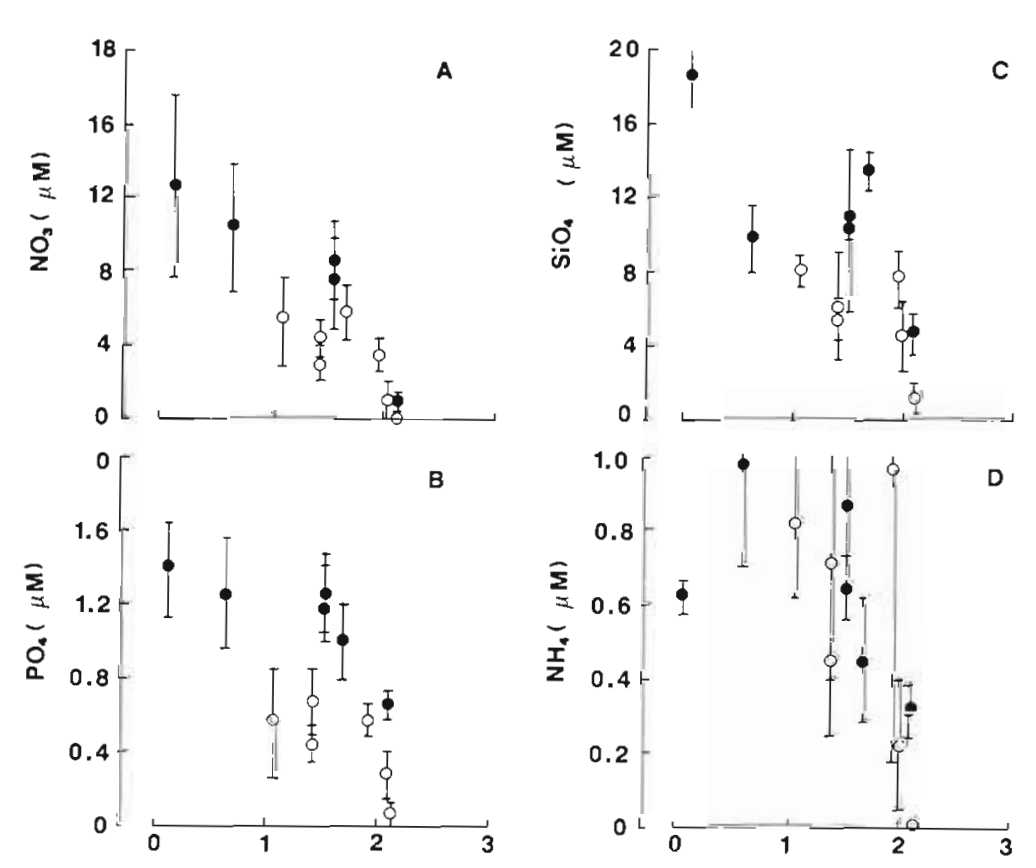

$\triangle$ TEMPERATURE $\left({ }^{\circ} \mathrm{C}\right)$

Fig. 5. Plots of temperature difference between the surface and the halocline $(\Delta t)$ against mean (A) nitrate, (B) phosphate, (C) silicic acid and (D) ammonium concentrations measured in the mixed layer in July 1979 (๑) and $1980(0)$ 

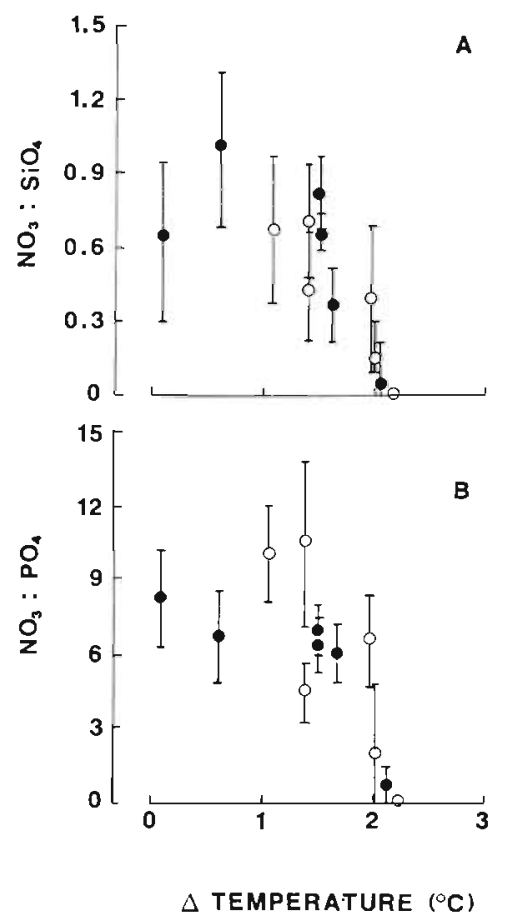

Fig. 6. Plots of temperature difference between the surface and the halocline $(\Delta \mathrm{t})$ against $(\mathrm{A})$ the ratio $\mathrm{NO}_{3}: \mathrm{SiO}_{4},(\mathrm{~B})$ the ratio $\mathrm{NO}_{3}: \mathrm{PO}_{4}$ calculated in the mixed layer in July 1979 and 1980 (o)

Subtracting the non-phytoplanktonic fraction (Yintercepts, Fig. 7) from each POC and PON value, we estimated the mean (standard deviation) phytoplanktonic POC:PON ratio in the mixed layer for each upwelling station (Table 1). The much lower values of the POC: PON ratio indicate higher intracellular levels of nitrogen in 1979 than in 1980. The higher values of the ratio in 1980 suggest nitrogen-limited phytoplankton growth during that cruise. No consistent changes of the ratio as a function of temperature were reported within each cruise.

\section{Phytoplankton species composition}

As expected in upwelling conditions, the phytoplankton community was dominated by diatoms during both cruises. In July 1979, Chaetoceros debilis and 3 species of Thalassiosira - T. pacifica, T. gravida and $T$. nordenskioldii - were the dominant diatoms at all stations (Table 2). Microflagellates were also present in significant numbers, while dinoflagellates were only observed in low numbers at Stn 7. July 1980, on the other hand, was characterized by a higher diatom diversity, but one species, T. pacifica, was largely dominant. The other important species were $T$. gravida, $T$. nordenskioldii and $C$. debilis, as observed in 1979, and 2 other Nitzschia species, N. longissima
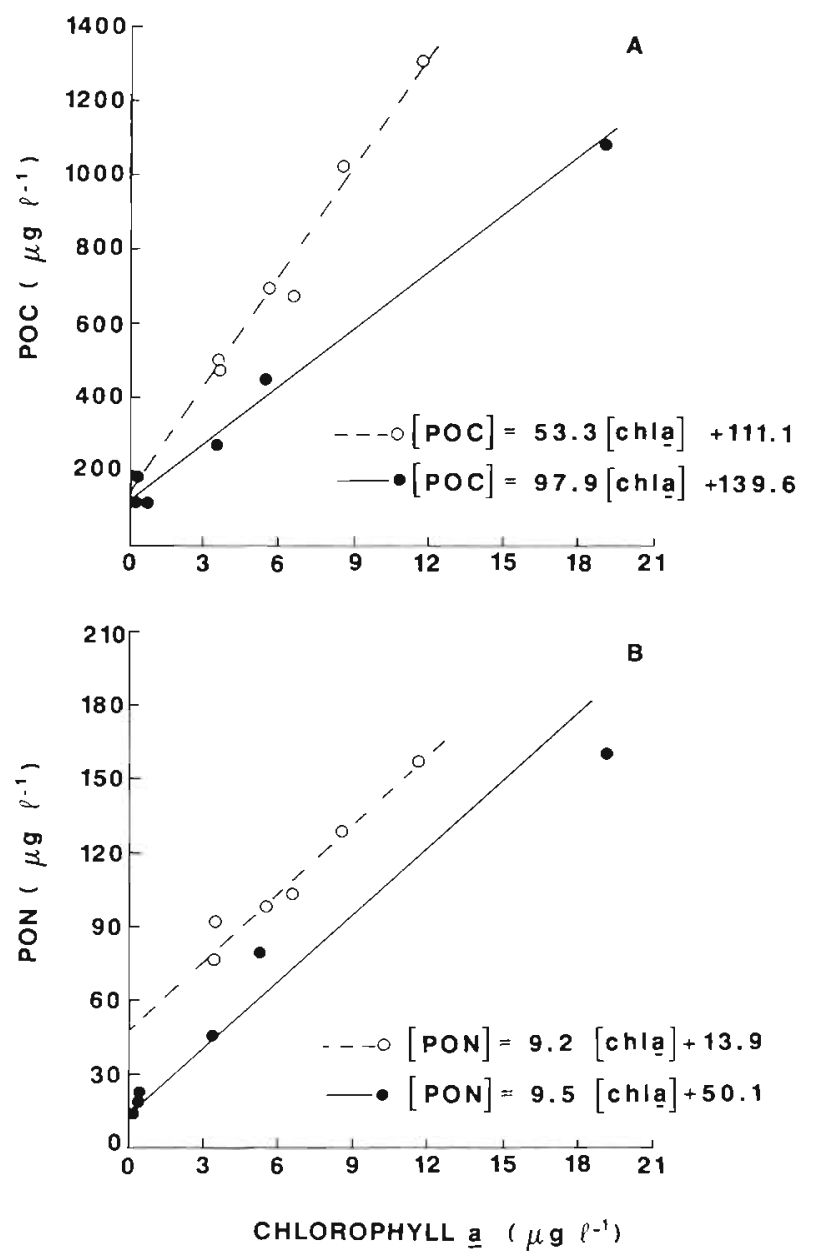

Fig. 7. Relations between the mean chlorophyll $a$ in the mixed layer and (A) mean POC, (B) mean PON concentrations in July $1979(\bullet)$ and $1980(0)$

Table 1. Mean (SD) POC: PON ratios in the mixed layer for each station during July 1979 and 1980 . The ratio could not be calculated at Stn 2 in July 1980 due to PON levels below estimated detritus levels

\begin{tabular}{|lcr|}
\hline Cruise & Stn no. & POC : PON \\
\hline July 1979 & 1 & $4.9(3.0)$ \\
& 4 & $5.0(0.7)$ \\
& 5 & $7.3(0.2)$ \\
& 7 & $5.0(0.1)$ \\
July 1980 & 8 & $5.5(2.3)$ \\
& 1 & $8.6(0.3)$ \\
& 2 & $8.5(0.5)$ \\
& 4 & $14.2(1.1)$ \\
& 5 & $10.8(0.7)$ \\
& 7 & $9.9(0.6)$ \\
& 8 & $11.2(0.5)$ \\
\hline
\end{tabular}

and $N$. delicatissima, were also found in significant numbers at Stn 7 . Dinoflagellates and microflagellates were also more numerous in 1980 than in 1979 . 
Table 2. Abundance of numerically important phytoplankton species ( $\times 10^{4}$ cells $\left.^{-1}\right)$ at $1.5 \mathrm{~m}$ depth during July 1979 and 1980

\begin{tabular}{|c|c|c|c|c|c|c|}
\hline \multirow[t]{2}{*}{ Phytoplankton community } & \multicolumn{6}{|c|}{ Stn no. } \\
\hline & 1 & 2 & 4 & 5 & 7 & 8 \\
\hline \multicolumn{7}{|l|}{ July 1979} \\
\hline Thalassiosira pacifica & 1.7 & 5.1 & 20.4 & 8.5 & 64.5 & 15.3 \\
\hline Thalassiosira gravida & 1.7 & & 13.6 & 1.7 & 22.5 & 3.4 \\
\hline Thalassiosira nordenskioldii & 3.4 & & 10.2 & 1.7 & 13.6 & 11.9 \\
\hline Chaetoceros debilis & 6.8 & 5.1 & 42.5 & & 129.5 & 15.3 \\
\hline Dinoflagellates & & & & & 1.5 & \\
\hline Microflagellates & 11.9 & 10.2 & 18.7 & 20.4 & 59.6 & 51.1 \\
\hline \multicolumn{7}{|l|}{ July 1980} \\
\hline Thalassiosira pacifica & 229.6 & 184.0 & 173.7 & 393.5 & & 373.0 \\
\hline Thalassiosira gravida & & & & & 8.6 & \\
\hline Thalassiosira nordenskioldii & & 1.7 & & 6.8 & 291.9 & 11.9 \\
\hline Chaetoceros debilis & 8.5 & & 3.4 & 18.7 & 20.4 & 22.1 \\
\hline Nitzschia longissima & & & & & 1.7 & \\
\hline Nitzschia delicatissima & & & & & 1.7 & \\
\hline Dinoflagellates & & & & 1.7 & & 3.4 \\
\hline Microflagellates & 30.7 & 56.2 & 46.0 & 124.4 & 81.8 & \\
\hline
\end{tabular}

\section{DISCUSSION}

Our data were collected non-synoptically at different locations (stations) in the upwelling area and, therefore, our results clearly indicate that within any one sampling cruise, we were observing the temporal development of a phytoplankton bloom following an upwelling event. There is also the indication that the 'age' of the bloom was different between the 2 cruises. Therefore, each station in the upwelling area exhibited a different stage of bloom development reached upon upwelling relaxation as indicated by the variability in surface heating (Fig. 3), nutrient concentrations (Fig. 5), phytoplankton biomass (Fig. 4) and species composition (Table 2). Our results suggest that the spatial and temporal variations in our survey area are consistent with the general model of Jones et al. (1983) and Maclsaac et al. (1985) who indicated that the diatom bloom development in upwelling areas could be divided into the following 4 zones or stages: Stage I, representing the upwelling center, and being characterized by high nutrient concentrations, low phytoplankton biomass and poor physiological state of the cells; Stage II, where phytoplankton begins to adapt to the new light and nutrient environment, following stabilization by solar heating: in this zone, Maclsaac et al. (1985) showed that algal cells were undergoing light-induced 'shift-up' to increase nutrient uptake and increase photosynthesis and synthesis of macromolecules; Stage III, characterized by a rapid increase of biomass and a drastic decrease of nutrient levels; and finally, Stage IV, characterized by nutrient exhaustion and cells exhibiting some signs of nutrient limitation ('shift-down', characterized by reduced growth rate and/or nutrient uptake rate and increasing sinking rate). In our results, variations in phytoplankton biomass and nutrient concentrations against temperature increments permit 2 major stages of bloom development to be distinguished. During the first part of upwelling relaxation $\left(\mathrm{T}=0\right.$ to $1.3^{\circ} \mathrm{C}$ ), the biomass remained at a low level (Fig. 4); nutrient concentrations were high and decreased slowly (Fig. 6). This result supports the hypothesis that phytoplankton cells go through an initial adaptation phase (Stage II) prior to entering the exponential growth phase (Stage III). Simulating upwelling conditions in the laboratory, Ishizaka et al. (1983) also observed the existence of a lag period preceding the bloom and demonstrated that the length of this period is temperature dependent, which supports the hypothesis that physiological adjustments occur The lag period was followed by a rapid increase in phytoplankton biomass (Fig. 4) and a rapid decrease in nutrient concentrations (Fig. 6).

The regular decrease of the nutrient concentrations in the mixed layer during the bloom development suggests that the upwelled water mass was functioning like a batch culture during the initial warm-up period. Therefore on theoretical grounds, the maximum phytoplankton yield should have been determined by the initial level of one limiting nutrient. The decrease in the $\mathrm{NO}_{3}: \mathrm{PO}_{4}$ ratios observed during the 2 cruises (Fig. 7) as well as the observed or predicted depletion of nitrate (Fig. $6 \& 8$ ) indicate that nitrate is most likely the limiting nutrient in this particular upwelling. Barlow 


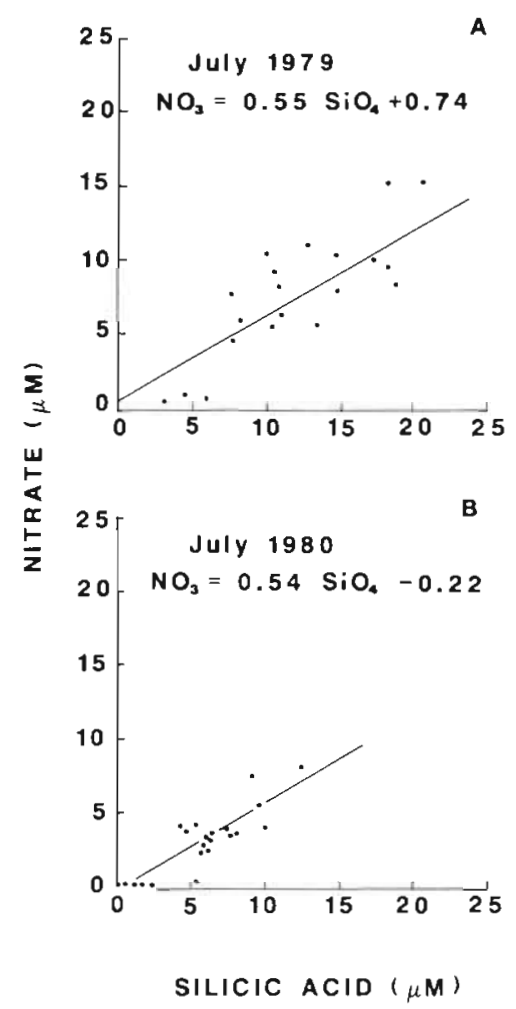

Fig. 8. Scatter diagram of nitrate versus silicic acid in the mixed layer in (A) July 1979 and (B) 1980. Curves were estimated using a Model II regression analysis

(1982a) showed that the nitrate depletion occurring during the upwelling relaxation may result in variations in the relative abundance of the different cellular constituents (ATP, proteins, chlorophyll a, carbohydrate and glucan). In our study, the low POC: PON ratios calculated for July 1979 (6.0) suggest that the algae were not nitrogen limited during this particular sampling occasion. On the other hand, the high values of this ratio for July 1980 (10.5) suggest that the development of the phytoplankton bloom had reached a more advanced stage (Stage IV) and that algae were nitrogen limited at most stations. The nitrogen limitation was also accompanied by a higher POC: Chl a ratio (97.9) in July 1980 than in July 1979 (53) (Fig. 5A).

Diatom growth may also be limited by ambient silicic acid concentrations even before all usable silicic acid is completely depleted. For example, Paasche (1973) reported silicic acid half-saturation constants varying from $0.8 \mu \mathrm{M}$ for Skeletonema costatum to $3.3 \mu \mathrm{M}$ for Thalassiosira species. Furthermore, Nelson et al. (1976) showed that most diatoms were having growth rates less than maximum at external silicic acid concentrations below $2.0 \mu \mathrm{M}$. In the estuary, concentrations of silicic acid below $2 \mu \mathrm{M}$ were observed in the upwelling area (Fig. 5). If we look at the nitrate-silicic acid relation at our upwelling stations, we find that during both cruises, the regression curves between $\mathrm{NO}_{3}$ and $\mathrm{SiO}_{4}$ in the mixed layer had similar slopes and $\mathrm{Y}$-intercepts (Fig. 8). The slopes of the Model II regression indicate that nitrate and silicic acid levels decreased in proportion of 0.5 to 1.0 in the mixed layer. The close to zero values of the Y-intercepts also indicate that these 2 nutrients were becoming exhausted nearly simultaneously. With the above considerations in mind, we cannot exclude possible and concurrent silicic acid limitation of diatom growth in our survey area.

\section{$\mathrm{NO}_{3}: \mathrm{SiO}_{4}$ ratios in upwelling areas}

As mentioned earlier, some studies have emphasized the possible role of the initial concentrations of nitrate and silicic acid in determining which of these nutrients will become depleted first in the newly upwelled water mass (Zentara \& Kamykowski 1977. Dugdale 1983). This means that knowing the initial nutrient ratio in the newly upwelled water mass and their uptake ratio by the phytoplankton community, we can predict which nutrient will become limiting first for diatom growth. Data from this study and other upwelling areas have been assembled in Table 3 , in order to test this hypothesis. Among the abundant literature on upwelling, only those studies containing the following information were selected: (1) the $\mathrm{NO}_{3}: \mathrm{SiO}_{4}$ ratio in the newly upwelled waters; (2) identification of the nutrient which first became depleted at the end of the exponential growth phase; and (3) the length of the bloom development (optional). Most of the data come from drogue studies and all the blooms were dominated by diatom species, except for one case (Baja California in March).

Table 3 highlights the dichotomy between nitrate and silicic acid exhaustion commonly observed in upwelling areas. The table indicates that the $\mathrm{NO}_{3}: \mathrm{SiO}_{4}$ ratio varies over a wide range (from 0.3 to 1.95 ) in the newly upwelled waters of the different upwelling systems. Depending on the water characteristics and the phytoplankton community, nitrate and silicic acid can be consumed in different proportions, ranging from $\sim 1.0: 2.5$ (Jennings et al. 1984, this study: see Fig. 8) to 2.0:1.0 (Treger \& Le Corre 1979, Minas et al. 1982). In spite of this wide range, a proportion of 1.0:1.0 can probably be considered as a reasonable estimate (Richards 1958, Redfield et al. 1963) for our purpose. Consequently, if biological (regeneration), chemical (dissolution) and physical (mixing) processes do not significantly affect these 2 nutrient pools at the scale of the phytoplankton bloom development, we can predict nitrate exhaustion in upwelled water masses with a $\mathrm{NO}_{3}: \mathrm{SiO}_{4}$ ratio $<1$ and silicic acid exhaustion for ratios $>1$. The results from Table 3 indicate that in all cases 
Table 3. Time scale of bloom development in the upwelling zone, initial levels and ratios of nitrate $\left(\mathrm{NO}_{3}\right)$ and silicic acid $\left(\mathrm{SiO}{ }_{4}\right)$ of the upwelled water mass, and the first exhausted nutrient at different upwelling locations and times of the year

\begin{tabular}{|c|c|c|c|c|c|c|c|}
\hline Location & $\begin{array}{l}\text { Period } \\
\text { of year }\end{array}$ & $\begin{array}{c}\text { Bloom } \\
\text { duration }\{d\}\end{array}$ & $\begin{array}{l}\mathrm{NO}_{3} \\
(\mu \mathrm{M})\end{array}$ & $\begin{array}{l}\mathrm{SiO}_{4} \\
(\mu \mathrm{M})\end{array}$ & $\begin{array}{l}\mathrm{NO}_{3}: \mathrm{SiO}_{4} \\
(\mu \mathrm{M}: \mu \mathrm{M})\end{array}$ & $\begin{array}{l}\text { First exhausted } \\
\text { nutrient }\end{array}$ & Source \\
\hline Peru upwelling & $\begin{array}{l}\text { Mar-Apr } 1966 \\
\text { Mar } 1977 \\
\text { Mar } 1977 \\
\text { Apr } 1966 \\
\text { Apr-May } 1976 \\
\text { Oct-Dec } 1977\end{array}$ & $\begin{array}{l}3 \\
4 \\
5 \\
3.5 \\
3 \\
-\end{array}$ & $\begin{array}{l}26.1 \\
21.0 \\
25.0 \\
17.9^{\circ} \\
10.0 \\
17.5\end{array}$ & $\begin{array}{l}19.4 \\
11.0 \\
20.0 \\
14.5 \\
18.0 \\
15.0\end{array}$ & $\begin{array}{l}1.33 \\
1.91 \\
1.25 \\
1.22 \\
0.55 \\
1.17\end{array}$ & $\begin{array}{l}\text { Silicic acid } \\
\text { Silicic acid } \\
\text { Silicic acid } \\
\text { Silicic acid } \\
\text { Nitrate } \\
\text { Nitrate }\end{array}$ & $\begin{array}{l}\text { Dugdale (1972) } \\
\text { Brink et al. (1981) } \\
\text { Maclsaac et al. (1985) } \\
\text { Whitledge (1981) } \\
\text { Huntsman et al. (1981) } \\
\text { Harrison et al. (1981) }\end{array}$ \\
\hline Benguela Current & Dec 1979 & 3 & 20.0 & 13.0 & 1.56 & Nitrate & Barlow (1982b) \\
\hline California upwelling & Mar 1972-1973 & 5 & 20.0 & 10.0 & 1.95 & Silicic acid & Minas et al. (1982) \\
\hline California upwelling & $\begin{array}{l}\text { Mar-Apr } 1981 \\
\text { Mar } 1971\end{array}$ & $\overline{4}$ & $\begin{array}{r}25.0 \\
8.0\end{array}$ & $\begin{array}{l}32.0 \\
14.0\end{array}$ & $\begin{array}{l}0.78 \\
0.57\end{array}$ & $\begin{array}{l}\text { Nitrate } \\
\text { Nitrate }\end{array}$ & $\begin{array}{l}\text { Jones et al. (1983) } \\
\text { Kamykowski (1974) }\end{array}$ \\
\hline Baja California & $\begin{array}{l}\text { Mar } 1972 \\
\text { Summer }\end{array}$ & - & $\begin{array}{r}4.0 \\
25.0\end{array}$ & $\begin{array}{l}13.0 \\
13.0\end{array}$ & $\begin{array}{l}0.31 \\
1.92\end{array}$ & $\begin{array}{l}\text { Nitrate } \\
\text { Silicic acid }\end{array}$ & $\begin{array}{l}\text { Walsh et al. (1974) } \\
\text { Walsh et al. (1974) }\end{array}$ \\
\hline St. Lawrence Estuary & Jul 1980 & - & 13.0 & 18.0 & 0.72 & Nitrate & This study \\
\hline $\begin{array}{l}\text { Laboratory simulation } \\
\text { Assuming a photic zo }\end{array}$ & of $35 \mathrm{~m}$ & 4 & 22.0 & 40.0 & 0.55 & Nitrate & Ishizaka et al. (1983) \\
\hline
\end{tabular}

where the initial ratio was $<1$, nitrate depletion was identified following the bloom development. Results from this study belong to this category. On the other hand, silicic acid depletion was usually observed for ratios $>1$. Although Table 3 is not exhaustive, it shows much of the data available from upwelling areas. The generally good agreement with the proposed relation (> $87 \%$ of the cases), which is more easily visualized from Fig. 9, emphasizes the importance of the initial relative concentration of the nutrients in determining which nutrient will control the magnitude of the diatom bloom development.

The apparent good fit between the predicted exhausted nutrient and the initial nitrate to silicic acid ratio in the upwelled water mass may, however, appear surprising since the high rate of regeneration of one of these nutrients may change the nutrient ratio drastically during bloom development and, consequently, obscure the proposed relation. Recently, Kamykowski \& Zentara (1985) showed that in the ocean, variations in ammonium contributions to the nitrogen utilized by diatoms (from 40 to $85 \%$ ) may shift the nitrate to silicic acid ratio towards nitrate or a silicic acid limitation of diatom growth. Since ammonium has been reported to be responsible for some 42 to $72 \%$ of the total biomass increase in different upwelling areas (see Table 10 in Whitledge 1981), it appears risky to ignore ammonium in any predictive model. On the other hand, high regeneration rates of nitrate and high dissolution rates of silicic acid may also occur in upwelling areas (Nelson \& Goering 1977, 1978) and prevent their complete depletion. With this information in mind, the overall good predictability of the proposed relation, or inversely, the apparent unimportance of regenerative processes in our predictions, can probably be explained

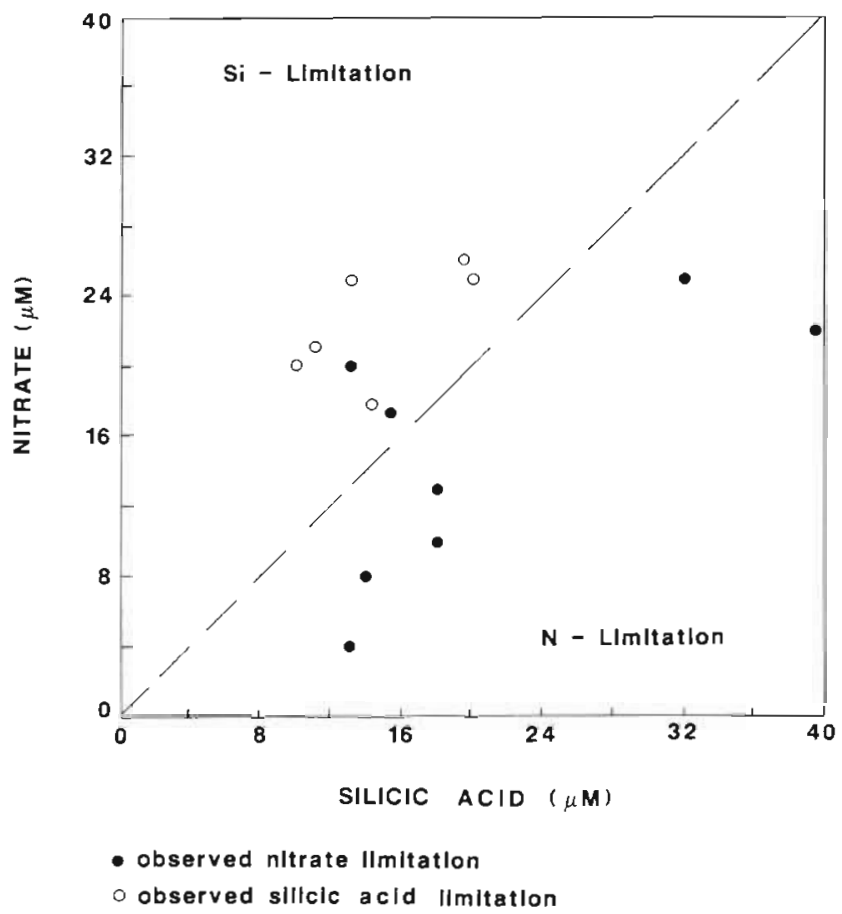

Fig. 9. Scatter diagram of initial concentrations of nitrate and silicic acid measured prior to the diatom bloom in the different upwelling areas (data from Table 3). Open and filled circles indicate that silicic acid or nitrate were first depleted at the end of the bloom development. Dotted line represents the predicted slope as the nutrients decrease assuming an uptake ratio of $1: 1$ 
by the very short duration of the diatom blooms reported in Table 3 ( 3 to 4 d) and from the associated high spatio-temporally localized demand in nutrient. During our study, the decrease of ammonium levels during the diatom blooms (Fig. 6) shows that ammonium was also consumed by algae and that uptake was probably exceeding the in situ regeneration rate during the exponential growth phase. Therefore this suggests that both the initial level of nitrogen and regenerative processes limit diatom growth at the scale of a bloom development in a newly upwelled water mass. It should also be noted that high nutrient demand may result not solely from increasing biomass, but also from an increase in the specific uptake rate as demonstrated for nitrate by Maclsaac et al. (1985).

\section{Vertical circulation dynamics of nitrate and silicic acid}

As stressed by Codispoti (1983), the importance of the initial nutrient concentrations shown in this study (Table 3; Fig. 9) implies that diatom growth in upwelling areas is mainly dependent on long-term regeneration processes and on factors controlling their accumulation in subsurface waters. Silicic acid and nitrate have different regenerative processes which lead to different vertical distributions. Silicic acid regeneration is mostly a dissolution process which occurs continuously at all depths in the ocean. On the other hand, the major part of pelagic nitrogen regeneration occurs near the surface, which reflects its strong link with biological activity (zooplankton excretion, bacterial remineralization, etc.). As a result of these different processes, the $\mathrm{NO}_{3}: \mathrm{SiO}_{4}$ ratio in oceanic environments will generally decrease with depth and stronger (deeper) upwelling will bring water with lower ratios to the surface. This hypothesis was put forward by Codispoti (1983) and Dugdale (1983) to explain the temporal shift between nitrate and silicic acid limitation in the Peru upwelling (Table 3).

A typical example of the vertical distribution of nitrate, silicic acid, phosphate and $\mathrm{NO}_{3}: \mathrm{SiO}_{4}$ ratio in the St. Lawrence upwelling area is shown in Fig. 10 (Stn 5, Jul 1980). In general, the concentrations of the 3 nutrients were variable in the upper $10 \mathrm{~m}$ (photic zone), depending on the stage of diatom bloom development. Their concentrations increased rapidly between 10 and $20 \mathrm{~m}$ and remained relatively unchanged between 20 and $100 \mathrm{~m}$. In this layer, nitrate levels were $\sim 11 \mu \mathrm{M}$, silicic acid concentration varied between 7 and $13 \mu \mathrm{M}$, phosphate concentration from 0.9 to $1.4 \mu \mathrm{M}$ and the resulting $\mathrm{NO}_{3}: \mathrm{SiO}_{4}$ ratio was in the range from 0.8 to 1.5. It should be noticed that the upwelled waters at the head of the Laurentian channel in the St. Lawrence estuary came from this layer between 20 and $100 \mathrm{~m}$ (Therriault \& Lacroix 1976). Below $100 \mathrm{~m}$, the concentration of each nutrient increased gradually with depth. Silicic acid exhibited the most drastic increase with concentrations reaching $30 \mu \mathrm{M}$ at $185 \mathrm{~m}\left(\mathrm{NO}_{3}: \mathrm{SiO}_{4}=\right.$
Fig. 10. Vertical distribution of (A) nitrate, phosphate and silicic acid, and $(B)$ nutrient ratios $\mathrm{NO}_{3}: \mathrm{SiO}_{4}$ and $\mathrm{NO}_{3}: \mathrm{PO}_{4}$ at $\operatorname{Stn} 5$ in July 1980

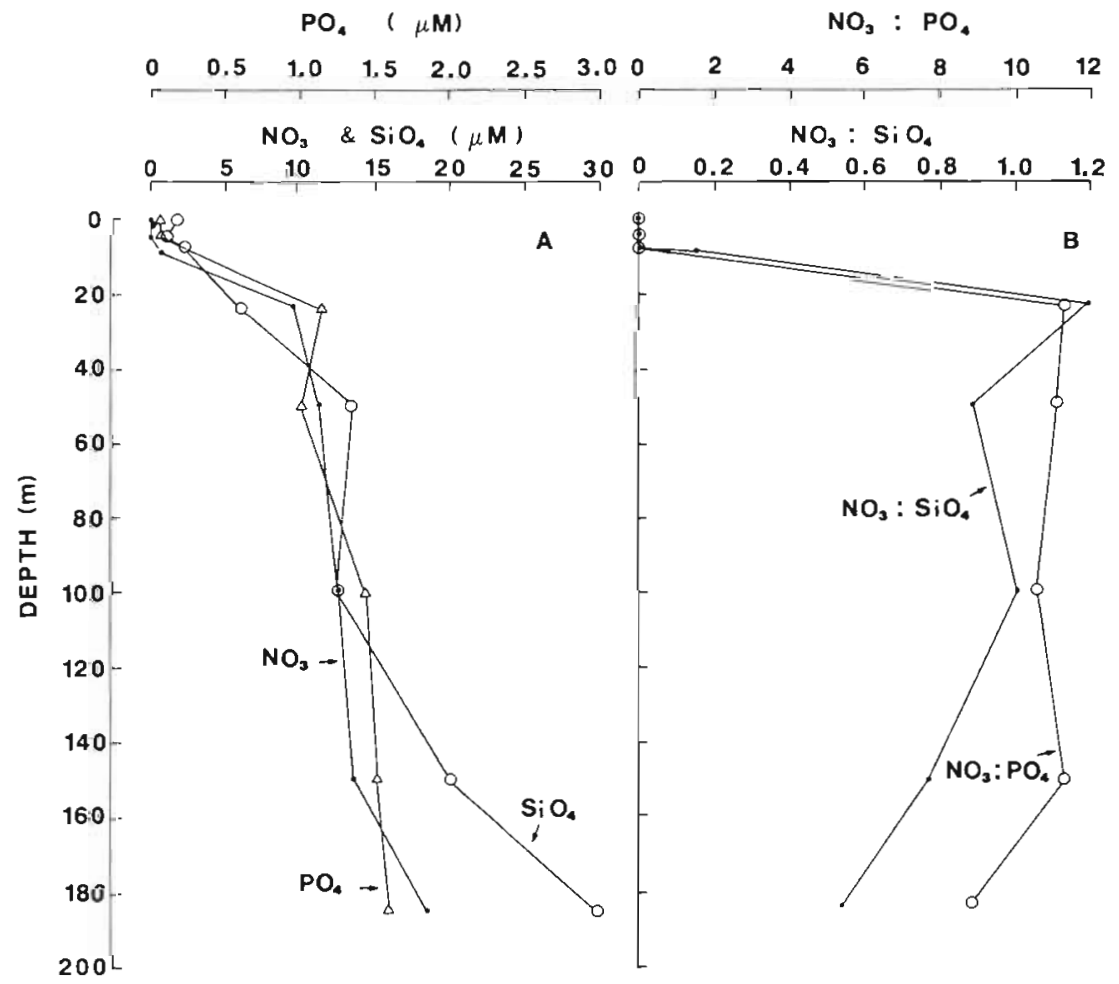


0.5). The important increase in silicic acid concentrations below $100 \mathrm{~m}$ and the associated decrease of the $\mathrm{NO}_{3}: \mathrm{SiO}_{4}$ ratio has also been observed in the St. Lawrence estuary by Coote \& Yeats (1979). It has been attributed to the estuarine circulation and its ability to trap silicic acid more efficiently than nitrate. While nitrate (and phosphate) are flushed out rapidly from the estuary due to their longer residence time in the surface layer where most of the regenerative processes are occurring, the incorporation of silicic acid into fastsinking particles (diatom theca and fecal pellets) enable them to accumulate in bottom waters where the residual circulation is in the upstream direction (Ingram 1979). Due to this accumulation of silicic acid in deep water, nitrate limitation of diatom growth is usually expected in all unpolluted systems characterized by an estuarine circulation, as was shown, for example, in Puget Sound (Winter et al. 1975) and in Saanich Inlet (Takahashi et al. 1977) where the $\mathrm{NO}_{3}: \mathrm{SiO}_{4}$ ratio in the newly 'upwelled or mixed' waters in those 2 environments was less than 0.5

In the St. Lawrence estuary, our results show that the trapping effect for silicic acid becomes significant only in deeper waters $(>100 \mathrm{~m}$ ). In the intermediate layer (20 to $100 \mathrm{~m}$ ), the nitrate and silicic acid concentrations were found generally in very similar proportions (Fig. 10). The fact that the upwelled waters at the head of Laurentian channel (Fig. 1) originate from this layer probably explains why simultaneous exhaustion of nitrate and silicic acid can occur in the St. Lawrence estuary.

Acknowledgements. The authors thank R. de Ladurantaye, J. Béchard, E. Bonneau, N. Gagnon, I. Lamontagne and J. Y. Bellavance for their participation in field collection and/or laboratory analyses of samples. We also thank D. Lefaivre, S. Demers and E. Sakshaug for stimulating discussions and J. Painchaud for his constant and critical support. Finally, we are grateful to L. Corriveau for drafting the figures and to P. J. Harrison and anonymous reviewers for their judicious comments.

\section{LITERATURE CITED}

Barlow, R. G. (1982a). Phytoplankton ecology in the southern Benguela Current. I. Biochemical composition. J. exp. mar. Biol. Ecol. 63: 209-227

Barlow, R. G. (1982b). Phytoplankton ecology in the southern Benguela Current. II. Dynamics of a bloom. J. exp. mar. Biol. Ecol. 63: 239-248

Boyd, C. M., Smith, S. L. (1983). Plankton, upwelling, and coastally trapped waves off Peru. Deep Sea Res. 30: $723-742$

Brink, K. H., Jones, B. J., van Leen, J. C., Mooevs, C. K. N., Stuart, D. W., Stevenson, M. R., Dugdale, R. C., Heburn, G. W. (1981). Physical and biological structure and variability in an upwelling center off Peru near $15^{\circ} \mathrm{S}$ during March, 1977. In: Richards, F. A. (ed.) Coastal upwel- ling. American Geophysical Union, Washington, D.C., p. 473-495

Codispoti, L. A. (1983). On nutrient variability and sediments in upwelling regions. In: Suess, E., Thiede, J. (ed.) Coastal upwelling. Plenum Press, New York, p. 125-145

Coote, A. R., Yeats, P. A. (1979). Distribution of nutrients in the Gulf of St. Lawrence. J. Fish. Res. Bd Can. 36: 122-131

Dugdale, R. C. (1972). Chemical oceanography and primary productivity in upwelling regions. Geoforum 2: 47-61

Dugdale, R. C. (1983). Effects of source nutrient concentrations and nutrient regeneration on production of organic matter in coastal upwelling centers. In: Suess, E., Thiede, J. (ed.) Coastal upwelling. Plenum Press, New York, p. $175-182$

Harrison, W. G., Platt, T., Calienes, R., Ochoa, N. (1981). Photosynthetic parameters and primary production of phytoplankton populations off the northern coast of Peru. In: Richards, F. A. (ed.) Coastal upwelling. American Geophysical Union, Washington, D.C., p. 303-311

Holm-Hansen, O., Lorenzen, C. J., Holmes, R. N., Strickland, J. D. H. (1965). Fluorometric determination of chlorophyll. J. Cons. int. Explor. Mer 30: 3-15

Huntsman, S. A., Brink, K. H., Barber, R. T., Blasco, D. (1981). The role of circulation and stability in controlling the relative abundance of dinoflagellates and diatoms over the Peru shelf. In: Richards, F. A. (ed.) Coastal upwelling. American Geophysical Union, Washington, D.C., p. $357-365$

Ingram, R. G. (1979). Water mass modification in the St. Lawrence Estuary. Naturaliste can. 106: 45-54

Ingram, R. G. (1983). Vertical mixing at the head of the Laurentian channel. Estuar. coast. Shelf Sci. 16: 333-338

Ishizaka, J., Takahashi, M., Ichimura, S. (1983). Evaluation of coastal upwelling effects on phytoplankton growth by simulated culture experiments. Mar Biol. 76: 271-278

Jennings, J. C., Jr., Gordon, L. I, Nelson, D. M. (1984). Nutrient depletion indicates high primary productivity in the Weddell Sea. Nature, Lond. 309: 51-54

Jones, B. H., Brink, K. H., Dugdale, R. C., Stuart, D. W., van Leer, J. C., Blasco, D., Kelly, J. C. (1981). Observations of a persistent upwelling center off Point Conception, California. In: Suess, E., Thiede, J. (ed.) Coastal upwelling. Plenum Press, New York, p. 37-60

Kamykowski, D. (1974). Physical and biological characteristics of an upwelling at a station off La Jolla, California during 1971. Estuar. coast. mar. Sci. 2: 425-432

Kamykowski, D., Zentara, S.-J. (1985). Nitrate and silicic acid in the world ocean: patterns and processes. Mar Ecol. Prog. Ser. 26: 47-59

Lund, J. W. G., Kipling, C., Lecren, E. D. (1958). The inverted microscope method of estimating algal numbers and the statistical basis of estimation by counting. Hydrobiologia 11: $143-170$

MacIsaac, J. J., Dugdale, R. C., Barber, R. T., Blasco, D., Packard, T T. (1985). Primary production cycle in an upwelling center. Deep Sea Res. 32: 503-529

Minas, H. J., Codispoti, L. A., Dugdale, R. C. (1982). Nutrients and primary production in the upwelling region off Northwest Africa. Rapp. P.-v. Réun. Cons. int. Explor Mer 180: 148-183

Nelson, D. H., Goering, J. J. (1977). Near-surface silica dissolution in the upwelling region off northwest Africa. Deep Sea Res. 24: 65-73

Nelson, D. M., Goering, J. J. (1978). Assimilation of silicic acid by phytoplankton in the Baja California and northwest Africa upwelling systems. Limnol. Oceanogr. 23: 508-517 Nelson, D. M., Goering, J. J., Kilham, S. S., Guillard, R. R. L. 
(1976). Kinetics of silicic acid uptake and rates of silica dissolution in the marine diatom Thalassiosira pseudomona. J. Phycol. 12: 246-252

Paasche, E. (1973). Silicon and ecology of marine plankton diatoms. II. Silicate-uptake kinetics in five diatom species. Mar Biol. 19: 262-269

Redfield, A. C., Ketchum, B. H., Richards, F. A. (1963). The influence of organisms on the composition of sea-water. In: Hill, M. N. (ed.) The sea, Vol. 2. Wiley and Sons, New York, p. 26-77

Richards, F. A. (1958). Dissolved silicate and related properties of some western North Atlantic and Carribbean waters. J. mar. Res. 17: 449-465

Sokal, R. R., Rohlf, F. S. (1981). Biometry. Freeman, San Francisco

Strickland, J. D. H., Parsons, T. R. (1972). A practical handbook of seawater analysis, 2nd edn. Bull. Fish. Res. Bd Can. 167: 1-310

Takahashi, M., Seibert, D. L., Thomas, W. H. (1977). Occasional blooms of phytoplankton during summer in Saanich Inlet, B.C., Canada. Deep Sea Res. 24: 775-780

Therriault, J. C., Lacroix, G. (1976). Nutrients, chlorophyll and internal tides in the St. Lawrence Estuary. J. Fish. Res. Bd Can. 33: 2747-2757
Therriault, J. C., Levasseur, M. (1985). Control of phytoplankton production in the lower St. Lawrence estuary: light and freshwater runoff. Naturaliste can. 112: 77-96

Treger, P., Le Corre, P. (1979). The ratios of nitrate, phosphate and silicate during uptake and regeneration phases of the Moroccan upwelling regime. Deep Sea Res. 26: 163-184

Walsh, J. J., Kelly, J. C., Whitledge, T. E., MacIsaac, J. J. (1974). Spin-up of the Baja California upwelling ecosystem. Limnol. Oceanogr. 19: 553-572

Whitledge, $T$ E. (1981). Nitrogen recycling and biological populations in upwelling ecosystems. In: Richards, F. A. (ed.) Coastal upwelling. American Geophysical Union, Washington, D.C., p. 257-273

Winter, D. F., Banse, K., Anderson, G. C. (1975). The dynamics of phytoplankton blooms in Puget Sound, a fjord in the northwestern United States. Mar. Biol. 29: 139-176

Yentsch, C. S., Menzel, D. W. (1963). A method for the determination of phytoplankton chlorophyll and phaeophytin by fluorescence. Deep Sea Res. 10: 221-231

Zentara, S.-J., Kamykowski, D. (1977). Latitudinal relationships among temperature and selected plant nutrients along the west coast of north and south America. J. mar. Res. 35: 321-337

This article was submitted to the editor; it was accepted for printing on March 31, 1987 